\title{
Audit Committee Characteristics and Audit Report Lag: Evidence From Oman
}

\author{
Nahla Abdulrahman Mohammed Raweh (Corresponding author) \\ Tunku Puteri Intan Safinaz School of Accountancy, College of Business \\ Universiti Utara Malaysia, 06010 UUM Sintok, Kedah, Malaysia \\ E-mail: nahlaraweh@gmail.com
}

Hasnah Kamardin

Tunku Puteri Intan Safinaz School of Accountancy, College of Business

Universiti Utara Malaysia, 06010 UUM Sintok, Kedah, Malaysia

E-mail: hasnahk@uum.edu.my

Mazrah Malik@ Malek

Tunku Puteri Intan Safinaz School of Accountancy, College of Business

Universiti Utara Malaysia, 06010 UUM Sintok, Kedah, Malaysia

E-mail: mazrah@uum.edu.my

Received: January 4, 2019

Accepted: January 21, 2019

Published: January 22, 2019

doi:10.5296/ijafr.v9i1.14170

URL: https://doi.org/10.5296/ijafr.v9i1.14170

\begin{abstract}
This study examines and provides empirical evidence on the association between audit committee characteristics and audit report lag, by using data from 255 companies listed in the Muscat Securities market from 2013 to 2017. Multivariate analyses show that audit committee size positively associated with audit report lag and audit committee financial expertise reduces audit lag. However, this study does not find evidence that audit committee independence and meetings are associated with audit report lag. This study concludes that internal mechanisms of corporate governance in Oman are not effective compared to more developed nations and that policymakers in this emerging market should enforce and
\end{abstract}


motivate practices of corporate governance in substance rather than simply adhering to practices in the form.

Keywords: Corporate governance, Audit committee, Audit report lag, Oman, Middle East countries

\section{Introduction}

Timeliness of financial reporting disclosure is a main component for accounting information quality. As stated by Financial Accounting Standards Board (FASB) in the Statement of Financial Accounting Concepts No.8, timeliness is considered as one of the fundamental qualitative characteristics of financial information quality and usefulness (FASB, 2010). Due to the recent high-profile accounting collapses, such as Enron and WorldCom that have shaken the investors' confidence about the efficiency of equity markets, both investors and legislators have become more concerned with the timeliness and the accounting information quality (Sultana, Singh \& Van der Zahn, 2015). Timeliness is deemed as a mirror that reflects the quality and reliability of financial information and its transparency (Ram \& Hassan, 2017), and promotes equality between stockholders to access financial information without the need to look for other sources (Owusu-Ansah, 2000).

The annual audit length has been specified as one of the most significant factors determining the timeliness of financial reporting by companies (Knechel \& Sharma, 2012; Abernathy, Barnes, Stefaniak \& Weisbarth, 2017). As required by regulations in several countries, companies are only allowed to issue their financial reporting after certification of external auditor and release the audit report (Abernathy et al., 2017). Audit lag is identified as the number of days from the end of company's fiscal year to the date of audit report (Swanson \& Zhang, 2018). Some research has shown that audit report lag is critical because it is related to public's confidence in the audited financial reports (Sultana et al., 2015; Salleh, Baatwah \&Ahmad, 2017). Delay of audit report jeopardises the quality of accounting information by not giving timely information to shareholders (Nor et al., 2010). Late disclosure of the auditor's opinion about the fairness of financial information results in increase asymmetric information and uncertainty in investment decisions (Afify, 2009; Mande \& Son, 2011). Hence, this may negatively influence investor's trust in the equity markets. Therefore, audit lag directly impacts the timeliness of financial reporting that affect the decision-making process (Ahmad, Mohamed \& Nelson, 2016).

The issue of timely provision of audited financial reporting is considered more important in emerging countries such as Gulf Corporation Countries (GCC) than in other countries because such reports are the only reliable source of information available to investors and other users who rely on these reports for investment decisions (Khasharmeh \& Aljifri, 2010; Basuony, Mohamed, , Hussain \& Marie, 2016), where the news outlets and intermediaries of financial in Gulf markets are not well developed compared with developed markets (Khasharmeh \& Aljifri, 2010; Baatwah, Salleh \& Ahmad, 2015a), as well as the regulatory bodies are non-effective (Amrah, Hashima \& Ariff, 2015). Previous studies have stated that audited financial reports disclosure in the Middle East Countries (MEC) including Oman is 
not in a timely manner and there is a significant lag in audit report timeliness behind those of developed economies (e.g. US and UK) (Afify, 2009; Baatwah et al., 2015a; Alfraih, 2016).

Given the importance of audit lag to investors, identifying the determinants of audit lag has been of interest of scholars as exhibited in recent research conducted by Abernathy et al. (2017), Sharma, Tanyi and Litt (2017), Wan-Hussin, Bamahros and Shukeri (2018) and Salehi, Bayaz and Naemi (2018). However, very few empirical studies investigated the factors impacting the lag of audit report in the MEC particularly with factors of corporate governance (see for example Afify, 2009; Baatwah et al., 2015a; Basuony et al., 2016). Thus, this study fills the gap in the prior literature by providing evidence on the relationship between audit committee and audit report lag in a unique setting such as the Middle East markets featured by high levels of secrecy and a lack of transparency.

In line with that, one of the main responsibilities of an audit committee (AC) is overseeing the process of financial reporting and external auditor's work, as well as strengthening the internal control (Bédard \& Gendron, 2010). Therefore, an AC is more likely to directly affect the activities and procedures of the external auditor, especially involving time taken to release the audit report positively. Theoretically, the agency theorists claim that audit committee is the most significant internal governance mechanisms to reduce agency conflict among managers and owners (Komal \& Bilal, 2016; Ika \& Ghazali, 2012) and ensures that better information flows between them by its overseeing function over the fundamental activities of business (Jensen, \& Meckling, 1976; Ika \& Ghazali, 2012). The AC is also the most important internal observing tool that can ensure the quality and timeliness submission of financial reporting (Afify, 2009; Shukeri \& Islam, 2012). In the same vein, AC can reduce the delay of audit report, by enhancing the internal control of client, hence minimize audit business risk and time of audit actions (Sultana et al., 2015). Previous literature had provided emphasis that the $\mathrm{AC}$ is effective in carrying out its duties if it has independent directors, expertise, sufficient size, and diligent (see for example Bédard \& Gendron, 2010, Kent, Routledge \& Stewart, 2010, Zaman, Hudaib \& Haniffa, 2011).

Past research had examined the relationship between AC characteristics (size, independence, financial expertise and meetings) and audit report lag (see for example Mohamad-Nor, Shafie \& Wan-Hussin, 2010; Shukeri \& Islam, 2012; Apadore \& Noor, 2013; Abernathy, Beyer, Masli \& Stefaniak, 2014; Sultana et al., 2015; Baatwah et al., 2015a; Salleh et al., 2017), however, the empirical findings from these studies were inconsistent. These researches mainly focused on data from developed markets like US and emerging markets such as Malaysia, where the legal framework is strict and the system of disclosure and transparency is developed. Furthermore, except for one study (see Baatwah et al., 2015a) which was conducted in Oman and had also failed to find any consistent significant correlation. This study reported that the practices of governance mechanisms in Oman are weak, and suggested that further research in this relationship is needed.

This study proceeds as follows: the next section is a review of corporate governance practices in Oman. Section three provides the hypotheses development. Section four details the 
research methodology. This is followed by the section of empirical results and finally, the conclusion.

\section{Corporate Governance in Oman}

The Omani government adopted many steps to guarantee the efficiency and effectiveness of the Muscat Security Market (MSM) and financial sector for developing the economy of country. Toward this improvement, it had issued the code of corporate governance for listed firms on the MSM in 2002 (Dry, 2003; Al-Busaidi, 2008). The Omani Corporate Governance Code (OCGC) is basically compliant with the principles of Organization for Economic Cooperation and Development (OECD) for corporate governance which focuses on five main points: (1) shareholders' rights, (2) the equitable dealing of all shareholders, (3) disclosure and transparency, (4) the duty of stakeholders in corporate governance, and (5) responsibilities of the board (OCGC, 2002). The OCCG identifies the mechanisms of composition and duties of the board of directors, audit committee, external auditors and internal control, executive management and the related party transactions. The code requires that board should include a majority of non-executive directors and one-third of whom independent, as well as, separate the roles of Chairman and CEO. The code recommends that the audit committee is responsible to assess the integrity of internal control and framework of risk management for company. The audit committee also is charged on overseeing and preparing financial reports on time. The code requests the audit committee to comprise of non-executive directors and a majority of members whom are independent, the size is at least three members with at least one of them has financial expertise, should held at least four meetings in a year, and the chairperson of the committee is independent. The OCGC was revised in 2015 and made mandatory in 2016 (became known as the 2016 code). It recommends the board to be composed of non-executive directors and train them in governance special programs, and to provide more safeguard for the minority shareholders. The revised code emphasizes the importance of the audit committee in overseeing and controlling the process of financial reporting and external auditor.

\section{Hypothesis Development}

Agency theory assumes that a strong system of internal control can strengthen the monitoring processes of company and, in turn, increases the credibility and quality of the financial information (Jensen \& Meckling, 1976). From the view of the agency theory, effective audit committee and external auditor are the main mechanisms to corporate monitoring and minimize the agency conflict that arises from information asymmetry between the owners and managers (Jensen \& Meckling, 1976; Shukeri \& Islam, 2012). By observing the management's behaviour and processes of financial reporting, provides greater assurance on the credibility and quality of financial statements (Fama \& Jensen, 1983). The agency theory literature confirms that the audit committee will be effective if it has these characteristics such as outside directors, expertise, resources (sufficient size) and activities (Ika \& Gazali, 2012; Ghafran \& Yasmin, 2018). These literatures revealed that the effectiveness of audit committee by its characteristics reduces the time of audit work and enhances the timeliness of financial information. Based on the perspective of agency theory, audit committee 
effectiveness is grounded on its characteristics to support the internal controls and external auditors (Zaman et al., 2011; Ika \& Gazali, 2012).

In Oman, the poor legal system to protect the wealth of minority shareholders, and high level of ownership concentration contribute to weak effectiveness of corporate governance (Young, Peng, Ahlstrom, Bruton \& Jiang, 2008; Hashim \& Amrah, 2016). Hence, the high agency conflicts found among substantial and minority shareholders (Hashim \& Amrah, 2016), results in the improvement of the system of corporate governance in Oman (see for example OCGC, 2002 and revised OCGC, 2015). This improvement focuses on the internal and external monitoring instruments and emphasis on the importance of audit committee in overseeing and controlling the process of financial reporting and external auditor, and ensures the protection of minority shareholders' interest. Thus, this study uses the characteristics of audit committee (e.g. size, independence, financial expertise and meetings) which explain the effectiveness of audit committee, to examine their impact in reducing the asymmetry of information and agency conflict between principle and agent, and among substantial and minority shareholders, that is through the capability of audit committee characteristics in shorting the lag of audit report.

\subsection{Audit Committee Size}

It is reported that, the sufficient size of audit committee could handle companies' issues in a more effective way (Sultana et al., 2015). The Blue Ribbon Committee (BRC) (1999) stipulates that three directors form a minimum size of audit committee. The OCGC (2002, revised 2015) states that the audit committee shall include at least three non-executive directors, with the majority of whom are independent directors. According to agency theory, the monitoring effectiveness and group cohesion can be enhanced by small audit committee size (Jensen, 1993; Hillman \& Dalziel, 2003). It is argued that an increase in audit committee size can result in lack of active participation by some directors, which in turn impairs cohesion in decision-making, and undermining the controlling and monitoring functions (Lipton \& Lorsch, 1992; Hillman \& Dalziel, 2003). Bédard and Gendron (2010) asserted that the audit committee with a small size has a diversity of expertise and can ensure the appropriate monitoring.

Contrary, other scholars have suggested that large committee size increases the variety of experience and sufficient resources, as well as improves the overseeing quality (Xie, Davidson \& DaDalt, 2003; Shukeri \& Islam, 2012). Previous studies have found that the AC size has a negative and significant association with audit report lag, indicating that more members in AC improve the timeliness of audit report (Mohamad-Nor et al., 2010; Shukeri \& Islam, 2012; Li, Zhang \& Wang, 2014). However, studies such as Wan-Hussin and Bamahros (2013) and Baatwah et al. (2015a) found an insignificant relationship between AC size and audit report lag, based on the above discussion, and incompatibility of views. Thus, the following hypothesis is developed:

H1: Audit committee size has associated with audit report lag. 


\subsection{Audit Committee Independence}

From the perspective of agency theory, independence and expertise of audit committee directors are much significant in maintaining the integrity of financial reporting and increase the monitoring quality as they are representatives of the shareholders and minority in particular (Watts \& Zimmerman, 1978; Fama \& Jensen, 1983).Independent directors have more motivation and expertise to reduce opportunistic behaviour, fraud and misleads in the accounting statements and in which to guarantee the interests of shareholders (Watts \& Zimmerman, 1978; Baatwah et al., 2015a), and the quality of financial information (Al-Rassas \& Kamardin, 2016). Moreover, directors with financial expertise in audit committee are more efficient when they are independent (Sharma \& Kuang, 2014).

Salleh et al. (2017) found that, audit committee financial expertise is not related to reducing audit report lag, while they did further examination if the board of director has a majority of independent directors, they revealed that audit committee financial expertise and independence significantly strengthen the timeliness of audit report. Some previous studies had found significant and negative association between audit committee independence and audit report lag (see for example Wan-Hussin \& Bamahros, 2013; Sultana et al., 2015). On the other hand, other researchers, for example Mohamad-Nor et al. (2010), Apadore and Noor (2013) and Baatwah et al. (2015a) found an insignificant relationship between audit committee independent directors and audit report lag. Accordingly, the following hypothesis is predicted:

$\mathrm{H} 2$ : Audit committee independence is negatively associated with audit report lag.

\subsection{Audit Committee Financial Expertise}

As stated by Bédard, Chtourou and Courteau (2004), the process of financial reporting and overseeing is the key responsibility of audit committee, and that such responsibility can only be achieved through directors who have extensive knowledge and experience in finance. McMullen and Raghunandan (1996) and Salleh et al. (2017) pointed out that, companies which suffer from financial problems give an indicator to the absence of financial experts in the audit committee. It is proven that audit committee financial expertise enhances significantly the demand for high audit quality (Yatim, Kent \& Clarkson, 2006). The agency theory claims that the existence of financial experts enhances the monitoring function of audit committee over the internal controls and ensures the efficiency of external auditor (Fama \& Jensen, 1983; Sultana et al., 2015).

Abernathy et al. (2014) had found that the audit committee with a high proportion of accounting and financial expertise is related to timely audit reports. Sultana et al. (2015) and Baatwah et al. (2015a) further found that the audit committees which have financial expertise led to reduce audit report lag. However, empirical evidence from Malaysia conflicts with this prediction and shows that audit report lag is not significantly associated with audit committee financial expertise (see for example Mohamad-Nor et al., 2010; Wan-Hussin \& Bamahros, 2013). Hence, this study hypothesis that:

H3: Audit committee financial expertise is negatively associated with audit report lag. 


\section{Mll Macrothink}

International Journal of Accounting and Financial Reporting

ISSN 2162-3082

2019, Vol. 9, No. 1

\subsection{Audit Committee Meeting}

Audit committee diligence (proxied by frequent meetings) may take many protective and corrective procedures on time regarding the weaknesses of internal control (Khlif \& Samaha, 2016), hence, able to detect and hinder the opportunistic behaviour of management and ensuring the integrity of earnings and quality of information reported (Bedard et al., 2004). Goh (2009) revealed that audit committee with frequent meetings is positively related to timely rectification of material weaknesses. As reported by BRC (1999), the audit committee should hold at least four meetings per year. Omani CMA emphasizes that the audit committee shall meet at least four times annually. Mohamad-Nor et al. (2010) suggested that, the audit committee have to meet frequently and write down its conclusions in carrying out its responsibilities and duties. The study also showed that, meeting frequency of audit committee can reduce the audit report lag.

In line with that, it is reported that, the frequent audit committee meeting boost the timelier of reporting (Ika \& Ghazali, 2012). In Jordan, Aljaaidi, Bagulaidah, Ismail and Fadzil (2015) found that, frequent audit committee meetings results to reduced delay in audit report. While other researchers found no relationship between audit committee meetings and audit report lag (see for example Baatwah et al., 2015a; Sultana et al., 2015; Salleh et al., 2017). Therefore, the following hypothesis is postulated:

H4: Audit committee meeting is negatively associated with audit report lag.

\section{Methodology}

\subsection{Sample Selection and Data Sources}

Data is retrieved from 119 listed companies on the Muscat Security Market (MSM) in 2017. Companies in MSM are classified into three sectors of industries namely financial, industrial, and service. The sample period is from 2013 to 2017. This period was selected due to the amendments which were done before 2013 to some items of the Omani corporate governance code, especially concerning the definition of independent director and the transactions of related parties by the MSM. Such amendments may consider some independent members based on the prior definition as non-independent members. The initial sample is 595 company-year observations. Financial listed companies (195 observations) are excluded because of their nature of business, governed by strict regulations and different rules as compared to non-financial companies (Mohamad-Nor et al., 2010; Baatwah et al., 2015a). Furthermore, 145 observations of uncompleted data among the period of the study are also eliminated. The final sample represents 255 observations for non-financial companies listed. Table 1 presents a summary for the distribution of the sample. Data is collected from annual reports of the listed companies in the MSM website. 
Table 1. Summary of the sample selection

\begin{tabular}{lllll}
\hline \multirow{2}{*}{ Items } & \multicolumn{2}{c}{ Distribution of industry } & \\
\cline { 2 - 5 } & Financial & Industrial & Service & Total \\
\hline Listed firms in 2013 & 39 & 42 & 38 & 119 \\
\hline Total observations 2013-2017 & 195 & 210 & 190 & 595 \\
\hline Minus financial firms & $(195)$ & - & - & $(195)$ \\
\hline Non-financial firms & - & 210 & 190 & 400 \\
\hline Minus incomplete firms & - & $(70)$ & $(75)$ & $(145)$ \\
\hline Total firms used in the analysis & - & 140 & 155 & 255 \\
\hline
\end{tabular}

Note: Distribution of Industry is based on the classification of MSM

\subsection{Variables Measurements}

The variables of this study include Audit Report Lag (ARL) as the dependent variable which is measured as the number of days between the end of company's year and audit report date (Salleh et al., 2017; Ghafran \& Yasmin, 2018). Whereas, audit committee characteristics as the independent variables include; Audit Committee Size (ACSZ) as the number of audit committee directors; Audit Committee Independence (ACI) as the proportion of independent audit committee directors; Audit Committee Financial Expertise (ACFEX) measured as the proportion of directors who qualify as accounting or financial experts in the audit committee; Audit Committee Meeting (ACM) measured as the number of audit committee meetings held annually (Mohamad-Nor et al., 2010; Salleh et al., 2017).

In addition, this study includes control variables which have been shown to have a significant effect on audit report timeliness (see for example Afify, 2009; Abidin \& Ahmad-Zaluki, 2012; Sultana et al., 2015; Basuony et al., 2016). Board Size (BOS) is measured as the number of directors in the board (Sultana et al., 2015). It is claimed that large board size has directors with diverse expertise may strengthen internal controls and capability of directors to monitor the actions of firm's management. Hence, reduce the late issuance of audit report (Basuony et al., 2016); Big4 audit firm (BIG4) is a dummy variable equal "1" if the firm was audited by one of the Big4 auditors and "0" otherwise (Al-Rassas \& Kamardin, 2016; Ghafran \&Yasmin, 2018). The recognized BIG4 audit firms have advanced resources, better technology and high expertise to provide the audit task by high quality and in faster time compared to non-Big4 firms (Alkhatib \& Marji, 2012) and hence, they will provide audit report in a shorter time (Basuony et al., 2016). Company Size (LOGSZ) is the natural log of total assets (Habib \& Bhuiyan, 2011; Abernathy et al., 2014). This control is important due to the claims that 
bigger company has a high tendency of making a strong internal control system and employs experienced accountants and is expected to assist auditors in reducing the timing of audit process (Habib \& Bhuiyan, 2011; Sultana et al., 2015). Leverage (LEV) measured as the ratio of the total debt to total assets (Khlif \& Samaha, 2016). Companies which are greater financed by debts have a higher business risk, hence, they are subjected to rigorous audits and take a long time (Abbott, Parker \& Peters, 2012; Dao \& Pham, 2014). Finally, Profitability (PROF), measured as the net income to total asset (Baatwa et al., 2015a; Alfraih, 2016). It is reported that companies' profitability can be considered as a sign of good management, hence, companies' management may request from auditors to issue the audit report in a short time to inform investors about the profits made as good news (Basuony et al., 2016).

\section{Empirical Model}

This study uses a panel data approach to determine the effect of audit committee effectiveness on audit report lag of the listed non-financial firms in Oman during the period of 2013-2017, the regression model is as follows:

$$
\begin{aligned}
\mathrm{ARL}_{\mathrm{it}} & =\beta_{0}+\beta_{1} \mathrm{ACSZ}_{\mathrm{it}}+\beta_{2} \mathrm{ACI}_{\mathrm{it}}+\beta_{3} \mathrm{ACFEX}_{\mathrm{it}}+\beta_{4} \mathrm{ACM}_{\mathrm{it}}+\beta_{5} \mathrm{BOS}_{\mathrm{it}} \\
& +\beta_{6} \mathrm{BIG}_{\mathrm{it}}+\beta_{7} \mathrm{LOGSZ}_{\mathrm{it}}+\beta_{8} \mathrm{LEV}_{\mathrm{it}}+\beta_{9} \mathrm{PROF}_{\mathrm{it}}+\varepsilon_{\mathrm{it}} \ldots
\end{aligned}
$$

Whereas: (i) represents every firm, and (t) represents every year, ARL is audit report lag, ACSZ is audit committee size, ACI is audit committee independence, ACFEX is audit committee financial expertise, ACM is audit committee meeting, BOS is board size, BIG4 is auditor type, LOGSZ is company size, LEV is leverage, PROF is profitability and $\varepsilon$ is the error term.

\section{Empirical Results and Discussion}

\subsection{Descriptive Statistics}

Table 2 illustrates the findings of descriptive statistics for all the variables of this study. It can be seen that the average of ARL is 51 days, with a variability of almost 11-days among companies under study, as well as a minimum of 25 and a maximum of 77 days, indicating that the full sample issues the audit report within 51 days. This result is similar to Baatwah et al's (2015a, b) evidence that records, on average Omani external auditors take 51 or 52 days to finalize the audit task. Compared with the developed economies, the result shows that ARL in Oman is somewhat close to ARL in the US and UK, on average, 55 and 64 days respectively (Abernathy et al., 2014; Ghafran \&Yasmin, 2018). And compared with the developing markets, such as Egypt and Malaysia, the average of ARL is 72 and 103 respectively (Khlif \& Samaha, 2014; Wan-Hussin et al., 2018), indicating that ARL in Oman is shorter. It is believed that this variance in ARL is basically due to the difference in deadline of reporting among countries. As for AC characteristics statistics, ACSZ has an average of about 3 members with a variation of almost 1 member among the sample, as well as a minimum of 0 and a maximum of 5 directors. While the mean of ACI is $81 \%$ of audit committee directors are independent with a variation of about $24.5 \%$, it has also a minimum value of $0 \%$ and a maximum of $100 \%$. The average of ACFEX is almost $43 \%$ of directors 
have financial expertise for the companies' sample, and a variation of $21.5 \%$, with a minimum of $0 \%$ and the maximum of $100 \%$. Finally, the ACM mean is 5 meetings held annually for the firms' sample with a minimum of 0 and a maximum of 11 meetings. Regards to the control variables, the mean of BOS is 7 directors. Furthermore, $61.6 \%$ of the companies are audited by the Big4 firms. The mean LOGSZ of the sample is about $17.1 \%$, suggesting that the companies size in the MSM is relatively small. The average for LEV and PROF are $47.3 \%$ and $5.5 \%$ respectively.

Table 2. Descriptive statistics results for variables (Company Observations $=255)$

\begin{tabular}{lllll}
\hline Variables & Mean & Std. Dev. & Min & Max \\
\hline ARL & 51.059 & 10.988 & 25.000 & 77.000 \\
\hline ACSZ & 3.424 & 0.738 & 0.000 & 5.000 \\
\hline ACI & 0.813 & 0.245 & 0.000 & 1.000 \\
\hline ACFEX & 0.428 & 0.215 & 0.000 & 1.000 \\
\hline ACM & 4.725 & 1.491 & 0.000 & 11.000 \\
\hline BOS & 7.271 & 1.514 & 3.000 & 12.000 \\
\hline BIG4 & 0.616 & 0.487 & 0.000 & 1.000 \\
\hline LOGSZ & 17.104 & 1.744 & 11.356 & 21.236 \\
\hline LEV & 0.473 & 0.348 & 0.053 & 2.629 \\
\hline PROF & 0.055 & 0.091 & -0.422 & 0.279 \\
\hline
\end{tabular}

\subsection{Univariate Analysis}

Table 3 presents the correlation matrix analysis (univariate analysis). This analysis shows the ARL is significantly correlated with ACFEX, BOS, LEV and PROF. The ACFEX has a negative and significant correlation with ARL for a value of $0.145(\mathrm{p}<0.05)$. This result provides initial support for $\mathrm{H} 3$, implying that companies with financial expertise in audit committee release their audit report in a timely manner. In contrast, ACSZ, ACI and ACM are insignificantly correlated with ARL. For control variables, BOS and PROF are negatively correlated with ARL at $\mathrm{p}<0.10$ and $\mathrm{p}<0.01$ respectively, indicating that BOS and PROF reduce ARL. While LEV has a positive correlated with ARL, which causes to increase ARL. Finally, BIG4 is not significantly correlated with ARL. Furthermore, the univariate analysis demonstrates the absence of multicollinearity issue in the study's model, where the highest 
correlation within explanatory variables is among LOGSZ and BIG4 at 0.50, which is less than the 0.80. Likewise, from the Table 3, the variance inflation factor (VIF) ranges from 1.12 to 2.36 that indicate the lack of multicollinearity issue. The VIF presents multicollinearity when its degree above 10 (Hair, Tatham, Anderson \& Black, 2006).

Table 3. Correlation matrix

\begin{tabular}{|c|c|c|c|c|c|c|c|c|c|c|c|}
\hline & ARL & ACSZ & $\mathrm{ACI}$ & ACFEX & $\mathrm{ACM}$ & BOS & BIG4 & LEV & LOGSZ & PROF & VIF \\
\hline ARL & 1 & & & & & & & & & & \\
\hline $\operatorname{ACSZ}$ & 0.071 & 1 & & & & & & & & & 1.46 \\
\hline $\mathrm{ACI}$ & 0.043 & $0.245^{* * * *}$ & 1 & & & & & & & & 1.24 \\
\hline ACFEX & $-0.145^{* *}$ & -0.038 & -0.002 & 1 & & & & & & & 1.12 \\
\hline $\mathrm{ACM}$ & 0.046 & $0.317^{* * * *}$ & $0.223^{* * *}$ & -0.091 & 1 & & & & & & 1.39 \\
\hline BOS & $-0.111^{*}$ & $0.327^{* * *}$ & $0.187^{* * * *}$ & $0.212^{* * * *}$ & $0.192^{* * *}$ & 1 & & & & & 1.54 \\
\hline BIG4 & 0.018 & $0.181^{* * * *}$ & $0.242 * * *$ & $0.161^{* * * *} *$ & $0.217^{* * * *}$ & $0.227 * * *$ & 1 & & & & 1.58 \\
\hline LEV & $0.191^{* * * *}$ & $-0.239 * * *$ & $-0.131^{* *}$ & -0.027 & $-0.139^{* *}$ & -0.032 & 0.018 & 1 & & & 1.34 \\
\hline LOGSZ & -0.042 & -0.028 & -0.031 & $0.218^{* * * * *}$ & $0.322^{* * * *}$ & $0.431^{* * *}$ & $0.508^{* * * *}$ & 0.084 & 1 & & 2.36 \\
\hline PROF & $-0.365^{* * *}$ & 0.031 & 0.049 & $0.141^{* * *}$ & 0.088 & $0.196^{* * * *}$ & $0.132^{* * *}$ & $-0.369 * * *$ & $0.351^{* * * *}$ & 1 & 1.43 \\
\hline
\end{tabular}

Note: ${ }^{*}{ }^{*} * * * * p$ - value $<0.10,0.05$ and 0.01 , respectively

\subsection{Regression Results}

Table 4 shows the regression results of the study model. Based on the panel corrected standard error that was used as a reliable model and provides reliable results. The results show that the audit report lag (ARL) model is significantly explained by the chosen variables (with $\mathrm{F}$ value $=6.05$ and $\mathrm{R}^{2}=0.1818$ ). For audit committee characteristics, the results present that ACSZ is significantly and positively related to ARL at $p<0.10$, representing that the prediction of $\mathrm{H} 1$ is accepted. This result is also consistent with the agency theory (Jensen, 1993), and Bédard and Gendron (2010) which suggest that the small-sized audit committee is better for coordination and communication between the directors, as well as enhancing the effectiveness of audit committee monitoring. Hence, small ACSZ contributes to shorten ARL. However, this result is in contrast with the evidence from others (see for example Mohamad-Nor et al., 2010; Shukeri \& Islam, 2012; Li et al., 2014).

Furthermore, it is also found that ACFEX has a significant negative association with ARL at $\mathrm{p}<0.01$. Thus, H3 is accepted. Such result is also supported by the agency theory that the presence of financial literacy supports audit committee to enhance internal controls and ensure the efficiency of external auditor to reduce the audit work time. This result is aligned with Abernathy et al. (2014) and Sultana et al. (2015). While inconsistent the findings of Mohamad-Nor et al. (2010) and Wan-Hussin and Bamahros (2013). Nevertheless, the findings show an insignificant association between ACI and ARL at $\mathrm{p}>0.10$. This finding contradicts $\mathrm{H} 2$. This result is also contradicted to the agency theory and prior investigations that proved that audit committee independence leads to reduce the delay in audit report and improve the timeliness of annual financial reporting (Wan-Hussin \& Bamahros, 2013; Sultana et al. 2015), but it is consistent with those of Apadore and Noor (2013), Baatwah et al. (2015a) and Salleh et al. (2017). For ACM, the result found ACM is negative but insignificant related to ARL at $\mathrm{p}>0.10$, hence $\mathrm{H} 4$ is not supported. This is in line with the results of Sultana et al. (2015), Baatwah et al. (2015a) and Salleh et al. (2017). However, this 
result is contrary with the findings of previous studies that revealed frequent meetings of audit committee has a significant role in minimizing audit report lag (see for example Mohamad-Nor et al., 2010; Aljaaidi et al., 2015).

This study provides some explanations for the findings of ACI and ACM. In Oman and the MEC in general, the independence of directors can be in form but not substantive. It is noted that a large ratio of independent members in listed companies are the main shareholders or executive directors of large shareholders. Additionally, existence of relatives is from second level and above as independent members in the top management of many companies. These cases may impede the role of independent directors in $\mathrm{AC}$ in monitoring and overseeing the processes of financial reporting and internal controls. Another reasonable explanation, the AC members are busy in solving the conflicts of directors like the related party transactions and provide a short time to discuss the issues of financial reporting, reports of external auditor and other related issues in meetings. Since the audit committee members are not independent in substance, hence they have less motivation in monitoring and discussing such as these issues (Baatwah et al., 2015a)

Regarding the control variables, Table 4 shows that the BOS and PROF are negatively and significantly associated with ARL, indicating that larger board and more profitable contribute to shorten ARL. These findings aligned with Alfraih (2016). While the coefficient of company size (LOGSZ) and LEV are positive and significant at $\mathrm{p}<0.05$, the result consistent with that revealed by Al-Ajmi (2008) and Leventis and Caramanis (2005). They reported that big companies' size, and companies that highly financed by debt need more audit effort and time due to their business risk. The results further showed the auditor type (BIG4) has no significant effect on ARL. This result is in line with the prior Arab countries research such as (Afify, 2009; Khasharmeh \& Aljifri, 2010; Aljaaidi et al., 2015; Baatwah et al., 2015a) that found Big-4 audit firms did not affect ARL. This may be attributed to that, in Oman the auditors lack adequate knowledge and expertise about their clients due to the short-term of auditors' tenure with their clients, which is two years for the majority of audit firms, hindering them from providing high audit quality (Baatwah, 2016).

Table 4. Regression results

\begin{tabular}{lllll}
\hline Variables & Prediction & Coef. & Z-stat & $\mathrm{P}>\mathrm{Z}$ \\
\hline ACSZ & $-/+$ & 2.066 & 1.920 & 0.055 \\
\hline ACI & - & 3.492 & 1.430 & 0.153 \\
\hline ACFEX & - & -4.702 & -3.050 & 0.002 \\
\hline ACM & - & -0.050 & -0.110 & 0.912 \\
\hline BOS & - & -1.095 & -2.750 & 0.006 \\
\hline
\end{tabular}




\begin{tabular}{lllll}
\hline BIG4 & - & -0.512 & -0.400 & 0.693 \\
\hline LOGSZ & + & 1.159 & 2.130 & 0.033 \\
\hline LEV & + & 2.431 & 2.540 & 0.011 \\
\hline PROF & - & -43.693 & -5.000 & 0.000 \\
\hline cons & & 33.115 & 3.580 & 0.000 \\
\hline F value & 6.05 & & & \\
\hline Prob > F & 0.000 & & & \\
\hline R-squared & 0.1818 & & & \\
\hline
\end{tabular}

\section{Conclusion and Future Research}

This study examines whether audit report lag is affected by audit committee characteristics namely size, independence, financial expertise and meetings in Oman setting. Investigation on the determinants of audit report lag is essential, especially in societies where the audited annual reports are the only source for providing the financial information to investors, such as the MEC. Based on 255 listed companies in MSM from 2013 to 2017, this study finds evidence of a significant positive relationship between audit committee size with audit report lag, suggesting that small audit committee size is associated in reducing audit report lag. The study further finds that audit committee with financial expertise enhances the timeliness of reporting by shortening audit report lag. Contrary, the findings also indicate that audit committee independence and meetings may not contribute to reducing audit report lag. The results are aligned with Baatwah (2016), who had also found that the characteristics of audit committee do not enhance the quality of financial reporting and concluded that the mechanism of audit committee is not effective in Oman. Hence, this study contributes to the body of knowledge by extending the literature of audit committee characteristics and audit report lag, particularly in the Middle East.

The findings can help regulators, firms and investors in Oman and other MECs in assessing the internal corporate governance mechanisms, for instance, the audit committee. As for regulators, such results could suggest for further attention to promote the independence and activity of the audit committee and also to review its existing policy. More focus should be placed on the composition of the board by policymakers in Oman and other GCC, and review is needed to the current definition of the director independence, as well as additional efforts to stimulate firms to employ independent directors substantively. Additionally, these results could help investors in making investment decisions more effectively. The study acknowledges that the findings should be held carefully due to that these results are set up on data from Oman market, where some scholars have noted some variances in the structures of 
corporate governance systems among the MEC (Baydoun, Maguire, Ryan, \& Willett., 2013; Baatwah et al., 2015a). Furthermore, the sample of the study is comparatively small and takes only non-financial sector, and the companies' size is relatively small in terms of their capitalization. Therefore, the generalizability of the results may be restrained through such two limitations. Thus, this study suggests that future research is needed to beat these limitations. Added to this, future research can consider the quality of companies' internal controls and whether audit reporting lag is related to earnings management or the cost of debt.

\section{References}

Abbott, L. J., Parker, S., \& Peters, G. F. (2012). Internal audit assistance and external audit timeliness. Auditing: A Journal of Practice \& Theory, 31(4), 3-20.

Abernathy, J. L., Barnes, M., Stefaniak, C., \& Weisbarth, A. (2017). An international perspective on audit report lag: A synthesis of the literature and opportunities for future research. International Journal of Auditing, 21(1), 100-127.

Abernathy, J. L., Beyer, B., Masli, A., \& Stefaniak, C. (2014). The association between characteristics of audit committee accounting expe rts, audit committee chairs, and financial reporting timeliness. Advances in Accounting, 30(2), 283-297.

Abidin, S., \& Ahmad-Zaluki, N. A. (2012). Auditor industry specialism and reporting timeliness. Procedia-Social and Behavioral Sciences, 65, 873-878.

Afify, H. A. E. (2009). Determinants of audit report lag: Does implementing corporate governance have any impact? Empirical evidence from Egypt. Journal of Applied Accounting Research, 10(1), 56-86.

Ahmad, M., Mohamed, H., \& Nelson, S. P. (2016). The Association between Industry Specialist Auditor and Financial Reporting Timeliness-Post MFRS Period. Procedia-Social and Behavioral Sciences, 219, 55-62.

Al-Ajmi, J. (2008). Audit and reporting delays: Evidence from an emerging market. Advances in Accounting, 24(2), 217-226.

Al-Busaidi, H. (2008). Oman's experience in issuing and implementation of the Code of corporate governance. Working Paper. In Corporate Governance Congress Dubai: IIR Middle East.

AlFraih, M. M. (2016). Corporate governance mechanisms and audit delay in a joint audit regulation. Journal of Financial Regulation and Compliance, 24(3), 292-316.

Aljaaidi, K. S., Bagulaidah, G. S., Ismail, N. A., \& Fadzil, F. H. (2015). An empirical invistigation of determinants associated with audit report lag in Jordan. Jordan Journal of Business Administration, 11(4), 963-980.

Alkhatib, K., \& Marji, Q. (2012). Audit reports timeliness: Empirical evidence from Jordan. Procedia-Social and Behavioral Sciences, 62, 1342-1349. 


\section{$\triangle$ Macrothink}

International Journal of Accounting and Financial Reporting

ISSN 2162-3082 2019, Vol. 9, No. 1

Al-Rassas, A. H., \& Kamardin, H. (2016). Earnings quality and audit attributes in high concentrated ownership market. Corporate Governance, 16(2), 377-399.

Al-Shammari, B., Brown, P., \& Tarca, A. (2008). An investigation of compliance with international accounting standards by listed companies in the Gulf Co-Operation Council member states. The International Journal of Accounting, 43(4), 425-447.

Baatwah, S. (2016). Audit tenure and financial reporting in Oman: Does rotation affect the quality?. Risk Governance \& Control: Financial Markets \& Institutions, 6(3), 18-29.

Baatwah, S. R., Salleh, Z., \& Ahmad, N. (2015a). Corporate governance mechanisms and audit report timeliness: empirical evidence from Oman. International Journal of Accounting, Auditing and Performance Evaluation, 11(3-4), 312-337.

Baatwah, S. R., Salleh, Z., \& Ahmad, N. (2015b). CEO characteristics and audit report timeliness: Do CEO tenure and financial expertise matter?. Managerial Auditing Journal, 30(8/9), 998-1022.

Basuony, M. A., Mohamed, E. K., Hussain, M. M., \& Marie, O. K. (2016). Board characteristics, ownership structure and audit report lag in the Middle East. International Journal of Corporate Governance, 7(2), 180-205.

Baydoun, N., Maguire, W., Ryan, N., \& Willett, R. (2013). Corporate governance in five Arabian Gulf countries. Managerial Auditing Journal, 28(1), 7-22.

Bédard, J., \& Gendron, Y. (2010). Strengthening the financial reporting system: Can audit committees deliver?. International Journal of Auditing, 14(2), 174-210.

Bedard, J., Chtourou, S. M., \& Courteau, L. (2004). The effect of audit committee expertise, independence, and activity on aggressive earnings management. Auditing: A Journal of Practice \& Theory, 23(2), 13-35.

Blue Ribbon Committee Report. (1999). Blue Ribbon Panel sends wake up call to sleepy audit committees. Washington, D. C.

Capital Market Authority. (2002). Code of corporate governance for Muscat Securities Market Listed Companies. Sultanate of Oman.

Capital Market Authority. (2016). Code of corporate governance for Muscat Securities Market Listed Companies. Sultanate of Oman. Retrieved from https://cma.gov.om/Home/DecisionsCirculars?sectionFilter=5\&yearFilter=\#

Dao, M., \& Pham, T. (2014). Audit tenure, auditor specialization and audit report lag. Managerial Auditing Journal, 29(6), 490-512.

Dry, E. K. (2003). Corporate Governance in the Sultanate of Oman. Richmond Journal of Global Law \& Business, 3(1), 45-82.

Fama, E. F., \& Jensen, M. C. (1983). Separation of ownership and control. Journal of Law and Economics, 26(2), 301-325. 


\section{$\triangle 1$ Macrothink}

International Journal of Accounting and Financial Reporting

ISSN 2162-3082 2019, Vol. 9, No. 1

Financial Accounting Standards Board (FASB). (2010). Conceptual framework for financial reporting.

Retrieved

from

http://www.fasb.org/resources/ccurl/515/412/Concepts\%20Statement\%20No\%208.pdf

Ghafran, C., \& Yasmin, S. (2018). Audit committee chair and financial reporting timeliness: A focus on financial, experiential and monitoring expertise. International Journal of Auditing, 22(1), 13-24.

Goh, B. W. (2009). Audit committees, boards of directors, and remediation of material weaknesses in internal control. Contemporary Accounting Research, 26(2), 549-579.

Habib, A., \& Bhuiyan, M. B. U. (2011). Audit firm industry specialization and the audit report lag. Journal of International Accounting, Auditing and Taxation, 20(1), 32-44.

Hair, J. F., Tatham, R. L., Anderson, R. E., \& Black, W. (2006). Multivariate Data Analysis. Upper Saddle River, NJ: Pearson Prentice Hall.

Hashim, H. A., \& Amrah, M. (2016). Corporate governance mechanisms and cost of debt: Evidence of family and non-family firms in Oman. Managerial Auditing Journal, 31(3), 314-336.

Hillman, A. J., \& Dalziel, T. (2003). Boards of directors and firm performance: Integrating agency and resource dependence perspectives. Academy of Management Review, 28(3), 383-396.

Ika, S. R., \& Ghazali, N. A. M. (2012). Audit committee effectiveness and timeliness of reporting: Indonesian evidence. Managerial Auditing Journal, 27(4), 403-424.

Jensen, M. C. (1993). The modern industrial revolution, exit, and the failure of internal control systems. The Journal of Finance, 48(3), 831-880.

Jensen, M. C., \& Meckling, W. H. (1976). Theory of the firm: Managerial behavior, agency costs and ownership structure. Journal of Financial Economics, 3(4), 305-360.

Kent, P., Routledge, J., \& Stewart, J. (2010). Innate and discretionary accruals quality and corporate governance. Accounting \& Finance, 50(1), 171-195.

Khasharmeh, H. A., \& Aljifri, K. (2010). The timeliness of annual reports in Bahrain and the United Arab Emirates: An empirical comparative study. The International Journal of Business and Finance Research, 4(1), 51-71.

Khlif, H., \& Samaha, K. (2014). Internal control quality, Egyptian standards on auditing and external audit delays: Evidence from the Egyptian Stock Exchange. International Journal of Auditing, 18(2), 139-154.

Khlif, H., \& Samaha, K. (2016). Audit committee activity and internal control quality in Egypt: Does external auditor's size matter?. Managerial Auditing Journal, 31(3), 269-289.

Knechel, W. R., \& Sharma, D. S. (2012). Auditor-provided nonaudit services and audit effectiveness and efficiency: Evidence from pre-and post-SOX audit report lags. Auditing: A Journal of Practice \& Theory, 31(4), 85-114. 


\section{Ml Macrothink}

International Journal of Accounting and Financial Reporting ISSN 2162-3082

Komal, B., \& Bilal. (2016). Audit committee financial experts' role in constraining earnings management: A narrative review and integrated model. Management and Administrative Sciences Review, 5(4), 187-202.

Leventis, S., \& Caramanis, C. (2005). Determinants of audit time as a proxy of audit quality. Managerial Auditing Journal, 20(5), 460-478.

Li, Y., Zhang, D., \& Wang, X. (2014). The influence of corporation governance structure on internal control audit report lag: evidence from China. Accounting \& Taxation, 6(2), 101-115.

Lipton, M., \& Lorsch, J. W. (1992). A modest proposal for improved corporate governance. The Business Lawyer, 48(1), 59-77.

Mande, V., \& Son, M. (2011). Do audit delays affect client retention?. Managerial Auditing Journal, 26(1), 32-50.

McMullen, D. A., \& Raghunandan, K. (1996). Enhancing audit committee effectiveness. Journal of Accountancy, 182(2), 79-81.

Mohamad-Nor, M. N., Shafie, R., \& Wan-Hussin, W. N. (2010). Corporate governance and audit report lag in Malaysia. Asian Academy of Management Journal of Accounting and Finance, 6(2), 57-84.

Owusu-Ansah, S. (2000). Timeliness of corporate financial reporting in emerging capital markets: Empirical evidence from the Zimbabwe Stock Exchange. Accounting and Business Research, 30(3), 241-254.

Ram, B. R., \& Hassan, A. N. (2017). Audit Quality and Audit Report Lag in Malaysia. Imperial Journal of Interdisciplinary Research, 3(10), 624-630.

Salehi, M., Lari Dasht Bayaz, M., \& Naemi, M. (2018). The effect of CEO tenure and specialization on timely audit reports of Iranian listed companies. Management Decision, $56(2), 311-328$.

Salleh, Z., Baatwah, S. R., \& Ahmad, N. (2017). Audit committee financial expertise and audit report lag: Malaysia further insight. Asian Journal of Accounting and Governance, 8, 137-150.

Sharma, D. S., Tanyi, P. N., \& Litt, B. A. (2017). Costs of mandatory periodic audit partner rotation: Evidence from audit fees and audit timeliness. Auditing: A Journal of Practice \& Theory, 36(1), 129-149.

Sharma, V. D., \& Kuang, C. (2014). Voluntary audit committee characteristics, incentives, and aggressive earnings management: Evidence from New Zealand. International Journal of Auditing, 18(1), 76-89.

Shukeri, S. N., \& Islam, M. A. (2012). The determinants of audit timeliness: Evidence from Malaysia. Journal of Applied Sciences Research, 8(7), 3314-3322.

Sultana, N., Singh, H., \& Van der Zahn, J. L. M. (2015). Audit committee characteristics and audit report lag. International Journal of Auditing, 2(19), 72-87. 


\section{Macrothink}

International Journal of Accounting and Financial Reporting

ISSN 2162-3082 2019, Vol. 9, No. 1

Swanson, Z., \& Zhang, Y. (2018). Do covenant violations affect audit report timeliness?. International Journal of Accounting, Auditing and Performance Evaluation, 14(1), 1-23.

Wan Hussin, W. N., Bamahros, H. M., \& Shukeri, S. N. (2018). Lead engagement partner workload, partner-client tenure and audit reporting lag: Evidence from Malaysia. Managerial Auditing Journal, 33(3), 246-266.

Wan-Hussin, W. N., \& Bamahros, H. M. (2013). Do investment in and the sourcing arrangement of the internal audit function affect audit delay?. Journal of Contemporary Accounting \& Economics, 9(1), 19-32.

Watts, R. L., \& Zimmerman, J. L. (1978). Towards a positive theory of the determination of accounting standards. Accounting Review, 53(1), 112-134.

Xie, B., Davidson, W. N., \& DaDalt, P. J. (2003). Earnings management and corporate governance: the role of the board and the audit committee. Journal of Corporate Finance, 9(3), 295-316.

Yatim, P., Kent, P., \& Clarkson, P. (2006). Governance structures, ethnicity, and audit fees of Malaysian listed firms. Managerial Auditing Journal, 21(7), 757-782.

Young, M. N., Peng, M. W., Ahlstrom, D., Bruton, G. D., \& Jiang, Y. (2008). Corporate governance in emerging economies: A review of the principal-principal perspective. Journal of Management Studies, 45(1), 196-220.

Zaman, M., Hudaib, M., \& Haniffa, R. (2011). Corporate governance quality, audit fees and non-audit services fees. Journal of Business Finance \& Accounting, 38(1-2), 165-197.

\section{Copyright Disclaimer}

Copyright for this article is retained by the author(s), with first publication rights granted to the journal.

This is an open-access article distributed under the terms and conditions of the Creative Commons Attribution license (http://creativecommons.org/licenses/by/4.0/) 